\title{
VALUE ADDED TAX IN REORGANISATION
}

\section{Václav Žalud, Jan Králíček*}

\begin{abstract}
This paper discusses the current Czech and European legal framework applicable to the adjustment to the taxable amount with respect to claims partially cancelled due to the insolvency of the customer resolved by reorganisation. The partial cancellation, according to the authors, serves as grounds to adjust a taxable amount under the EU VAT Directive. The supplier is entitled to issue a corrective invoice and claim a refund of a proportion of the VAT paid with respect to the delivery of goods or services to an insolvent debtor. However, such practice is not yet followed by the Czech tax authorities who do not allow for a reduction of a taxable amount in reorganisation and only allow such reductions in the case of bankruptcy liquidation. The paper argues that this approach is not compatible with European law. Moreover, such a different treatment of VAT payers in bankruptcy liquidation (resulting in higher satisfaction of VAT taxpayers as creditors) puts reorganisation at a considerable disadvantage and is contrary to the basic principles of insolvency law. Finally, the paper argues that the corresponding claim of the tax authority resulting from the VAT base adjustment constitutes a standard pre-insolvency claim and should not be preferred in the insolvency proceedings under Czech law.
\end{abstract}

Keywords: reorganisation, value added tax, insolvency

JEL Classification: K34, H25

\section{Introduction}

The reorganisation (in Czech reorganizace) of MOTORPAL, a.s. was one of the first which intensively opened the question of whether creditors that are VAT payers may make an adjustment to the output VAT taxable amount in the event of partial cancellation (in Czech zánik) of their claims as a result of the reorganisation plan's entry into effect. The question concerns the right to deduct part of the paid VAT as in the case of a bankruptcy liquidation (in Czech konkurs) which has a special legal regulation in Czech law pursuant to Section 44 of the VAT Act. Given that the average level of satisfaction of claims of unsecured creditors in reorganisations was approximately 24\% between 2008 and 2014 (Schönfeld, 2015) and is currently even less, often not even in single digits per cent, ${ }^{1}$ the additional "satisfaction" corresponding to the VAT deduction may be crucial for the creditors' decision to support reorganisation rather than bankruptcy liquidation.

The model situation is as follows: the taxable transaction provider delivers goods or provides a service to the customer. Both are VAT payers. The supplier pays the output VAT from the transaction provided, and the customer asserts its entitlement to deduct the input VAT. Subsequently, the customer is unable to meet its financial obligations towards

1 Cf. the reorganisations of OKD, a.s., VÍTKOVICE ENVI a.s. or VÍTKOVICE GEARWORKS a.s.

* Václav Žalud is an attorney-at-law and Jan Králíček is an articling attorney clerk, both working in the international law firm Dentons (https://www.dentons.com/en/). 
the supplier and the insolvency of the customer is declared. Therefore, the supplier registers its claim from the aforesaid transaction in insolvency proceedings. The customer's insolvency is resolved by reorganisation and, within the fulfilment of the reorganisation plan, the claims registered in the insolvency proceedings are only partially satisfied.

Although the General Financial Directorate (GFD) expressed a negative view of the possibility of making an adjustment to the output VAT taxable amount in reorganisation, the matter now appears to be resolved by the later case law of the European Court of Justice which, in substantially similar proceedings, disagreed with the position of the GFD and supported the solution proposed within the successful reorganisation of MOTORPAL, a.s.

\section{The Legal Framework for Adjustment to the Amount of VAT and the VAT Taxable Amount}

In the case of bankruptcy liquidation, adjustment to the taxable amount and to the amount of tax is specifically regulated in Section 44 of the VAT Act. Under this provision, the taxpayer which, in the course of a chargeable event in relation to another payer, became obliged to declare tax and whose claim arising in the period ending six months before the court's decision on bankruptcy liquidation, is entitled to make an adjustment to the amount of the output tax from the value of the established claim under the conditions specified therein.

Historically, the provision of Section 44 of the VAT Act was neutral ${ }^{2}$ with respect to the method of insolvency resolution (i.e. it is applied regardless of whether insolvency was resolved by a reorganisation or a bankruptcy liquidation) although it was later exclusively limited to bankruptcy liquidations.

Therefore, we believe that Section 44 of the VAT Act cannot be applied in the case of reorganisation. However, we hold the view that it is possible to apply a general rule contained in Section 42 of the VAT Act, taking into account the obligation to interpret this provision in accordance with the rules of the EU law, as stated below. This provision stipulates under subsection (1)(b) that the payer (a creditor in insolvency proceedings) shall make an adjustment to the taxable amount and to the amount of tax (inter alia) if the reduction of the taxable amount pursuant to Sections 36 and 36a of the VAT Act occurs after the date of the chargeable event (in Czech den uskutečnění zdanitelného plněni). Pursuant to Section 36 of the VAT Act, the taxable amount is defined as everything that the creditor has or is to receive as consideration in return for the taxable transaction conducted, including the amount for the payment of excise duty, from the party for whom the taxable transaction is conducted or from a third party.

The provision of Section 42 of the VAT Act represents the transposition of Council Directive 2006/112/EC on the Common System of Value Added Tax (the VAT Directive). Pursuant to Article 90 of the VAT Directive, it applies that:

"In the case of cancellation, refusal or total or partial non-payment, or where the price is reduced after the supply takes place, the taxable amount shall be reduced accordingly under conditions which shall be determined by the Member States."

Furthermore, Article 90 (2) of the VAT Directive states that only in the case of total or partial non-payment of the price may the Member States derogate from the aforementioned rule and set in national legislation that taxable amount reduction is

2 Cf. the wording of Section 44 of the VAT Act before the amendment made by Act No. 502/2012 Coll. 
now allowed. In contrast, in other cases (cancellation of a transaction, termination of a transaction, reduction in the price after the date of the chargeable event), adjustment to the taxable amount is mandatory, and no derogation is allowed.

Therefore, it is necessary to distinguish the following situations:

- (partial) non-payment of the purchase price, where the original claim of the taxpayer continues to exist ("...the purchaser remains liable for the agreed price and the seller ... in principle continues to have the right to receive payment, which he can rely on in court" - judgment of the European Court of Justice in Case C-337/13, Agrárkülkereskedelmi, Paragraph 25);

- reduction in the price (received for the transaction) after the date of the chargeable event due to (partial) cancellation (termination) of the payer's original claim.

Most reorganisation plans are based on the restructuring of creditors' claims, consisting of the remission of part of the debtor's debts (Section 341(1)(a) of the Insolvency Act), i.e., cancellation of the claims registered in the insolvency proceedings. The provision of Section 356 (1) of the Insolvency Act implies that after the reorganisation plan's entry in effect, the claims of the debtor's creditors are cancelled. After the reorganisation plan's entry in effect, only the parties listed in the reorganisation plan under the conditions laid down therein, including the scope of their claims, are deemed to be the debtor's creditors. It follows that the reorganisation plan (partially) cancels any pre-insolvency claims.

The strict distinction between (partial) non-payment of the price and the reduction in the price with cancellation of the original claim is accentuated by the Court of Justice of the European Union, which confirmed the Member States may derogate from the VAT Directive only in the event of total or partial non-payment of the price of the transaction, but not in the latter case of a reduction in the price.

The EU legislature intended to leave it to each Member State to decide whether the situation of non-payment of the purchase price leads to an entitlement to have the taxable amount reduced accordingly under the conditions determined by each Member State, or whether such a reduction is not allowed in that situation at all, since it cannot be determined that such a debt will become definitively irrecoverable (judgment in Case C-337/13, Almos Agrárkülkereskedelmi, Paragraph 25; identically in Case C-404/16, Lombard Ingatlan Lizing, Paragraph 29).

Unfortunately, this case law of the European Court of Justice later became one of the arguments of the GFD to reject the adjustment to the taxable amount in reorganisation, even though it was strictly limited to cases of total or partial non-payment, characterised by uncertainty as to whether such non-payment is definitive or not (judgment in Case C-404/16, Lombard Ingatlan Lizing, Paragraph 30).

Conversely, in the event of a reduction in the price, the debt corresponding to the taxable transaction is definitely irrecoverable. Therefore, the European Court of Justice ruled that the reduction of a debtor's obligations resulting from the final approval of an arrangement with creditors ${ }^{3}$ in the insolvency proceedings does not constitute a case of

3 This term is the equivalent of the reorganisation plan under the Czech Insolvency Act; the arrangement with creditors under Slovenian law in the dispute in question determined that the debtor would only be obliged to pay to its creditors $44 \%$ of its debts within the period of 9 years. 
a transaction remaining totally or partially unpaid (judgment in C-396/16, T-2, družba za ustvarjanje, razvoj in trženje elektronskih komunikacij in opreme, d.o.o., Paragraph 45). Therefore, the European Court of Justice ordered the national court to determine the effect of the arrangement with the creditors on the creditors' claims (taxable transactions) (C-396/16, Paragraph 42). ${ }^{4}$

According to the European Court of Justice, if the court stated that the debtor's obligations were reduced to such an extent that the corresponding part of the suppliers' claims against the debtor became definitively irrecoverable, these are not transactions that have remained totally or partly unpaid. To assess the definitive nature of a claim, account must be taken, in particular, of the economic and commercial reality (judgment in Joined Cases C-53/09 and C-55/09, Loyalty Management UK and Baxi Group, Paragraph 39, as well as C-653/11, Newey, Paragraph 42).

The effect of the reorganisation plan in most cases leads to (partial) cancellation of claims which is definitive, as opposed to mere non-payment of claims. The adjustment to the taxable amount in reorganisation should, therefore, be admissible as ordered by the European Court of Justice. In accordance with Article 90(1) of the VAT Directive 5 and the provision of Section 42(1)(b) of the VAT Act, the creditor should, therefore, be obliged to make an adjustment to the taxable amount after the reorganisation plan has become effective.

Adjustment is made by issuing the corrected tax invoice within 15 days from the identification of the facts decisive to make such adjustment (effectiveness of the reorganisation plan, unless the reorganisation plan provides for the claim to be cancelled later). Adjustment to the taxable amount and to the amount of tax may not be made after the expiration of the period of three years from the end of the taxable period in which the tax liability for the original taxable transaction was incurred.

Pursuant to the provision of Section 74(1) of the VAT Act (again in accordance with Article 185(1) of the VAT Directive, ${ }^{6}$ as the basis for the transposition of that provision into national legislation), the debtor's mirror obligation arises to make an adjustment to the tax deduction in the taxable period when it became aware of the decisive circumstances for an adjustment. This is again the point when the reorganisation plan becomes effective unless laid down by the reorganisation plan that the claim (or any part thereof) is cancelled later.

4 The Court of Justice ordered the national court to assess whether under the applicable national law, after the final approval of the arrangement with creditors, the purchaser remains liable for the agreed price and the seller or supplier continues to have the right to receive payment, which it can rely on before the courts

5 The Court of Justice of the European Union even confirmed that Article 90(1) of the VAT Directive has a direct effect and that taxable persons may rely on it before the national courts because that provision is unconditional and sufficiently precise (C-337/13, Almos Agrárkülkereskedelmi, paragraph 40).

6 With regard to this provision of the VAT Directive, we further state that the judgment in Case C-396/16 concerned the interpretation of the provisions of Article 185(1) and (2) of the VAT Directive and, therefore, that the necessary consequence of the adjustment to the taxable amount and to the amount of tax on the part of the creditors is an adequate adjustment to the deduction (and increase in the tax liability) on the part of the debtor. 


\section{Incorrectness of the Financial Administration's Opinion}

However, it is surprising that the aforementioned conclusions of the applicable legislation in the EU-conforming interpretation of the relevant provisions of the VAT Act are not taken into account in the financial administration's decision-making practice. The aforementioned conclusions were presented within the GFD Coordination Committee with the Chamber of Tax Advisers of the Czech Republic on 25 January 2017 and 10 May 2017. The GFD's attitude can be interpreted as negative, viewing the adjustment to the amount of VAT and the VAT taxable amount in reorganisation as inadmissible, arguing as follows:

“... as a result of the reorganisation of the creditor's claims, a claim will in fact not become definitively irrecoverable as a result of the unpaid consideration for the taxable transaction carried out against the debtor and, therefore, it is not the final cancellation of the claim as assumed by the Court of Justice of the European Union in Paragraph 25 of the judgment cited above (note: a reference to Case C-337/13, Almos Agrárkülkereskedelmi), and a reduction in the taxable amount of value added tax pursuant to Section 42(1)(b) of the VAT Act, therefore, cannot be applied, because under abovementioned Paragraph 25 of the aforementioned decision of the Court of Justice of the European Union, this is an unpaid tax, with a possible derogation under Paragraph 2 of Article 90 from the application of Paragraph 1 of the same article (as assumed by the Court of Justice of the European Union)."

and:

"The Czech State has so far dealt with the category of non-payment of the price in full or in part in accordance with Article 90 (2) of the Directive in Section 44 of the VAT Act. In its application practice, the financial administration has relied on Section 44 of the VAT Act in cases of non-payment of the price, allowing an adjustment only if the conditions specified therein have been met in full compliance with the intent that was adopted in the legislative creation of this provision."

The GFD unconvincingly argues by referring to the provisions of the Insolvency Act, namely Section 362 and Section 363 of the Insolvency Act. Under these provisions, the insolvency court may revoke the decision to approve the reorganisation plan or decide to convert a reorganisation into bankruptcy liquidation. However, such an interpretation is untenable because the tax authority is bound by the final decisions of the competent authorities within the meaning of Section 99(1) of the Tax Code (in this case, it is bound by a final court decision to approve the reorganisation plan), and it cannot even make its own preliminary judgment on whether a criminal offence has been committed within the meaning of Section 362(2) of the Insolvency Act (Section 99(2) of the Tax Code).

In addition, in order to support this opinion, the GFD states that under Section 356(3) of the Insolvency Act, the creditors' rights in relation to the debtor's co-debtors and guarantors remain unaffected by the reorganisation plan, so the creditor may recover the claim in the original amount even after the reorganisation plan has become effective. The provision of Section 356(3) of the Insolvency Act, however, only seeks to break the 
principle of guarantee accessoriness and does not address the issue of recoverability of the creditor's actual claim (taxable transaction) against the debtor. In addition, if this were to be the reason to distinguish between non-payment and a reduction in the price, then the tax administrator should not recognise the entitlement to VAT deduction only where the claim (taxable transaction) was secured by such instruments.

In its conclusion, the GFD admits in its opinion that a transfer from a set of cases characterising non-payment of the purchase price to a set of cases of reduction in the price after the transaction was conducted would only be possible on the basis of the result of the decision of the Court of Justice of the European Union in Case C 396/16 (cited above).

As mentioned above, in the time after the original opinion of the GFD was issued, the European Court of Justice agreed with the supporters of the opinion that adjustment to the taxable amount in reorganisation is permissible and, therefore, we believe that the GFD will review its opinion, observing the decision of the European Court of Justice.

\section{Practical Aspects of Asserting Entitlement in Relation to the Tax Administrator}

The authors' experience shows that in practice the tax administrator does not recognise the creditors' entitlement to make an adjustment to the amount of VAT and to the VAT taxable amount as a result of the reorganisation plan's effect, with reference to the GFD's reasoning. The tax administrator rejects both the adjustment to the taxable amount on the part of creditors and the corresponding adjustment to the tax deduction made by the debtor in reorganisation. Thus, the tax administrator paradoxically refuses an adjustment to the tax deduction made in the debtor's tax return for the period in which the reorganisation plan became effective where the debtor declares a lower deduction entitlement and, therefore, a higher tax liability (!). In view of this attitude of the tax administrator, there is an absurd situation where the debtor declares a higher tax liability, which the tax administrator denies. The debtor, which under the law must act in insolvency proceedings to ensure that its creditors receive the highest satisfaction possible (and are able to make a valid adjustment to the amount of VAT and to the VAT taxable amount), must then defend itself against the tax administrator's finding of the non-existence of such tax, which is a highly unusual situation.

Another issue connected with this paradox is the nature of the tax administrator's claim against the debtor. Pursuant to Section 168(2)(e), claims with administrative priority, if arising after the declaration of insolvency, also include "claims arising as a result of an adjustment to the amount of tax on claims against the debtor in insolvency proceedings under the law regulating value added tax". In the past, based on the interpretative opinion of the expert group for insolvency law, ${ }^{7}$ the court practice concluded that the state's claim arising as a result of an adjustment to the taxable amount of value added tax against the debtor in insolvency proceedings is not an asset claim. However, this interpretation was adopted prior to the amendment to the Insolvency Act by Act No. 294/2013 Coll., which changed the cited provision of Section 168(2)(e) of the Insolvency Act, meaning that it was only because of this amendment that the text cited in the above paragraph was inserted into this provision.

7 Interpretative opinion No. 6 of the Expert Group for Insolvency law of 4 October 2011. 
However, according to the explanatory memorandum to Act No. 294/2013 Coll., the above amendment was intended to refer to Section 44 of the VAT Act (which applies exclusively to a bankruptcy liquidation), not to common adjustments to the taxable amount under Section 42 of the VAT Act, which, as mentioned above, occur during reorganisation. Therefore, it can be argued that in the event of a reduction in the asserted tax deduction under Section 74 of the VAT Act following the adjustment to the taxable amount and to the amount of tax on the part of creditors in reorganisation under Section 42 of the VAT Act, the cited provision of the Insolvency Act does not apply, and the tax administrator's claim is, therefore, not a claim with administrative priority.

In addition, several decisions (including the one made by the High Court in Olomouc) ${ }^{8}$ were made in the past according to which the state's claims arising as a result of an adjustment to the VAT taxable amount pursuant to Section 44 of the VAT Act are not claims with administrative priority. Under this case law, claims do not arise after a declaration of insolvency if, factually, these claims are merely a transformation of the supplier's claim, i.e. a claim arising before the declaration of insolvency. Similar argumentation can be used in the case of adjustment under Section 42 of the VAT Act, where the law also stipulates (in Paragraph 3) that this is an independent taxable transaction, but the tax rate, as well as exchange rate conversions, are based on the original taxable transaction (cf. Section 42 (4) of the VAT Act). Therefore, it can be concluded that even in this case only a transformation of the pre-insolvency claim occurs and that the establishment of the tax administrator's claim as a new claim arising after the declaration of insolvency is only legal fiction under the VAT Act.

The case law of the High Court in Prague has so far unambiguously considered the state's claims arising as a result of an adjustment to the taxable amount under Section 44 of the VAT Act to be claims with administrative priority. ${ }^{9}$ This argumentation was later supported by another panel of judges of the High Court in Olomouc, which, however, pointed to the variance of the case law in this issue. ${ }^{10}$ For the time being, we do not know of any of the Supreme Court's case law after the amendment of Section 168(2)(e) of the Insolvency Act implemented by Act No. 294/2013 Coll. that would correct this variance nor any case law that would apply to the situation in reorganisation, i.e. to the adjustments under Section 42 of the VAT Act in conjunction with Section 74 of the VAT Act.

The authors of this article believe that a purely grammatical interpretation of the provision of Section 168(2)(e) of the Insolvency Act (whether in the case of a reorganisation or a bankruptcy liquidation) is discriminatory and establishes a preferential position of the tax administrator over other pre-insolvency creditors. In the case of the tax administrator's claim, there is a close link between such a claim as a result of an adjustment to the VAT deduction and the pre-insolvency claims of the creditors. The creditors must register their claims (and usually receive a pro-rata satisfaction), but the tax administrator does not have to do so, although the tax administrator's claim is only a transformation of the preinsolvency claims as a result of the reduction in the price. Therefore, the tax administrator's claim should receive the same treatment as the other pre-insolvency creditors.

8 For example, Decision of the High Court in Olomouc of 19 March 2013, Ref. No. 3 VSOL 19/2013B-113.

9 Decision of the High Court in Prague of 24 September 2015, Ref. No. 101 VSPH 343/2015-49.

10 Decision of the High Court in Olomouc of 7 September 2016, Ref. No. 11 VSOL 6/2016-57. 
If the interpretation of Section 168(2)(e) of the Insolvency Act is not corrected in conformity with the Constitution, the authors believe that this provision of the law should be repealed by the Constitutional Court. Any practical problems associated with the time aspects of registering the tax administrator's claims arising as a result of an adjustment to the taxable amount ${ }^{11}$ can be addressed by giving the tax administration a subsequent possibility to register the claim in insolvency proceedings even after expiry of the registration period.

Any other interpretation would mean for the creditors that their potential additional satisfaction consisting of reimbursement of part of the VAT paid to the state would not be of any benefit to them because the performance in the same amount would have to be paid by the debtor (at the expense of the creditors) from the assets determined to satisfy them, namely to cover such a claim of the tax administrator (asserting to have the aforesaid administrative priority).

Until the law is clarified, it can be recommended that a debtor in reorganisation (or, as the case may be, the insolvency administrator in a bankruptcy liquidation) requests the court to order the tax administrator to assert its claim as a result of an adjustment to the VAT taxable amount by an action under Section 203a of the Insolvency Act. It is the insolvency court that is most competent to decide on the nature of the claim, i.e. to decide whether the claim by a tax administrator has administrative priority, or it is a standard pre-insolvency claim. If such an action is not brought by the tax administrator or if it is dismissed, such a claim is a pre-insolvent claim by operation of law. In order for the solution to be fair, such a claim should not be rejected on grounds of delayed filing after the expiry of the period for registrations (Section 185 in conjunction with Section 173(1) of the Insolvency Act), given that the period of time for registering claims to the tax administrator expires before the creditors make an adjustment to the taxable amount (see footnote 13 above). Therefore, the tax administrator should be allowed to apply its entitlement subsequently, but as a pre-insolvency claim in insolvency proceedings.

\section{Conclusion}

In this article, we have attempted to draw attention to an incorrect opinion of the financial administration and, in particular, to the incorrect procedure of the tax administrator in practice, in which it does not regard the (partial) cancellation of claims due to the effectiveness of the reorganisation plan as a fact leading to the adjustment to the amount of VAT. The financial administration does not allow adjustment to the VAT taxable amount on the part the debtor's creditors based on Section 42 of the VAT Act and, at the same time, the adjustment to the tax deduction on the part of the debtor under Section 74 of the VAT Act. As we explained in the second part of this article, this procedure is not in line with EU law and with the interpretation of the Court of Justice of the European Union in the current decisions.

This procedure used by the tax administrator in specific cases jeopardises the very possibility of implementing a reorganisation solution for corporate insolvency because, from the point of view of creditors and the level of their possible satisfaction, this solution is

11 As these claims only "arise" long after the expiration of the period of time for registration of claims, especially in the case of reorganisations. 
significantly disadvantageous compared to bankruptcy liquidation, where the adjustment to the amount of VAT is recognised as possible by the tax administrator. The financial administration's argumentation for a discriminatory interpretation is inappropriate, mixing various reasons for adjustment to tax and, based on a misinterpretation of the provisions of the insolvency law and European case law.

In the final part of the article, we attempted to present the issue of the nature of the tax administrator's claim arising as a result of an adjustment to the VAT deduction on the part of the debtor, concluding that such a claim should not have the nature of a claim with administrative priority and that the dispute regarding the nature of this claim should be dealt with by a court within the insolvency proceedings.

\section{Abbreviations}

- VAT - value added tax

- GFD - General Financial Directorate

- Insolvency Act - Act No. 182/2006 Coll., on insolvency and methods of its solution

- VAT Directive - Council Directive 2006/112/EC of 28 November 2006 on the common system of value added tax

- VAT Act - Act No. 235/2004 Coll., on value added tax

\section{Sources}

Schönfeld, J. (2015). Insolvency Proceedings - Expectations, Reality, Future [online]. Available at: http://www.vyzkuminsolvence.cz/data/files/2015-senat-seminar/6-schonfeldreorganizace-vs-sanacni-konkurz.pdf [Accessed 15 May 2018]

Judgment of 7 October 2010, Loyalty Management UK and Baxi Group, C-53/09 and C-55/09, EU:C:2010:590

Judgment of 12 October 2017, Lombard Ingatlan Lízing, C-404/16, EU:C:2017:759

Judgment of 15 May 2014, Almos Agrárkülkereskedelmi Kft, C-337/13, EU:C:2014:328

Judgment of 20 June 2013, Newey, C-653/11, EU:C:2013:409

Judgment of 22 February 2018, T-2, družba za ustvarjanje, razvoj in trženje elektronskih komunikacij in opreme, d.o.o., C-396/16, ECLI:EU:C:2018:109

Judgment of 23 November 2017, Di Maura, C-246/16, EU:C:2017:887

Decision of the High Court in Olomouc of 19 March 2013, Ref. No. 3 VSOL 19/2013-B-113

Decision of the High Court in Prague of 24 September 2015, Ref. No. 101 VSPH 343/2015-49

Decision of the High Court in Olomouc of 7 September 2016, Ref. No. 11 VSOL 6/2016-57

Council Directive 2006/112/EC of 28 November 2006 on the common system of value added tax Interpretative opinion No. 6 of the Expert Group for Insolvency Law of 4 October 2011

Act No. 182/2006 Coll., on insolvency and methods of its solution

Act No. 235/2004 Coll., on value added tax

Act No. 294/2013 Coll., amending Act No. 182/2006 Coll., on insolvency and methods of its solution (Insolvency Act) 